\title{
Sea Otter, Enhydra lutris, Sightings off Haida Gwaii / Queen Charlotte Islands, British Columbia, 1972-2002
}

\author{
Kimberly Raum-SuRYAN ${ }^{1,3}$, KenNETH PITCHER ${ }^{1}$, and Richard LAMY ${ }^{2}$ \\ ${ }^{1}$ Alaska Department of Fish and Game, Division of Wildlife Conservation, 525 W. $67^{\text {th }}$ Avenue, Anchorage, Alaska 99518 USA; \\ e-mail: kraumsuryan@charter.net \\ ${ }^{2}$ Gwaii Haanas National Park Reserve/Haida Heritage Site, P.O. Box 37, 120 Second Avenue, Queen Charlotte, British Columbia \\ V0T 1S0 Canada \\ ${ }^{3}$ Current address: 928 NW Cottage Street, Newport, Oregon 97365 USA
}

Raum-Suryan, Kimberly, Kenneth Pitcher, and Richard Lamy. 2004. Sea Otter, Enhydra lutris, sightings off Haida Gwaii/Queen Charlotte Islands, British Columbia, 1972-2002. Canadian Field-Naturalist 118(2): 270-272.

On 27 June 2001 we observed and photographed a Sea Otter (Enhydra lutris) adjacent to a Steller Sea Lion (Eumetopias jubatus) haulout near Sgang Gwaay (Anthony Island), Haida Gwaii / Queen Charlotte Islands. This is one of only eight documented sightings of Sea Otters in these waters during the past 30 years. These sightings may represent the beginning of the expansion of Sea Otters to their former range off Haida Gwaii.

Key Words: Sea Otter, Enhydra lutris, Haida Gwaii, Queen Charlotte Islands, British Columbia.

The Sea Otter (Enhydra lutris) once ranged in nearshore waters along the North Pacific Rim from Japan to Baja California. The worldwide population of Sea Otters in the early 1700s was estimated to be between 150000 (Kenyon 1969) and 300000 animals (Johnson 1982). Middens (human food waste mounds) indicate that aboriginal people, including the Haida, hunted Sea Otters (Simenstad et al. 1978; Acheson 1998; Sloan 2004). Although this harvest may have caused local reductions of Sea Otter populations near village sites (Simenstad et al. 1978), the species was abundant throughout its range prior to commercial exploitation. Following the advent of commercial hunting in 1741, the worldwide population of Sea Otters declined to less than 2000 animals by 1911 , limited to remnant groups throughout the range (Kenyon 1969). Many of these remnant groups (including one group located off the Haida Gwaii / Queen Charlotte Islands, British Columbia, Canada) were extirpated, likely due to their small size (Watson et al. 1997). The last Sea Otter recorded from Haida Gwaii was before 1920 (Kenyon 1969) and the last recorded in British Columbia, near Vancouver Island (prior to reintroduction), was in 1929 (Cowan and Guiguet 1960; Kenyon 1969).

In 1911 an International Treaty provided protection of Sea Otters from additional exploitation. Furthermore, to aid in the recovery of Sea Otters, various translocation projects were conducted from the 1950s to early 1970s in the Pacific coastal United States and Canada (Kenyon and Spencer 1960; Kenyon 1969; Burris and McKnight 1973; Bigg and MacAskie 1978; Jameson et al. 1982; Jameson et al. 1986; Riedman and Estes 1990). Since reintroduction, the Sea Otter population in British Columbia has increased 18.6\% per year from 70 animals in 1977 to an estimated 2500 animals in 1998 (Watson 2000). Although Sea Otters continue to expand their range along Vancouver Island and the central coast of British Columbia (Watson
2000; Figure 1), sightings off Haida Gwaii / Queen Charlotte Islands remain rare.

On 27 June 2001 we observed and photographed a Sea Otter of unknown sex adjacent to a Steller Sea Lion haulout $\left(52^{\circ} 04.966^{\prime} \mathrm{N}, 131^{\circ} 13.811^{\prime} \mathrm{W}\right)$ just south of Sgang Gwaay (Anthony Island), Haida Gwaii / Queen Charlotte Islands (Figure 1). The Sea Otter was swimming on its back eating a sea urchin (Strongylocentrotus sp.). We observed the otter for approximately $30 \mathrm{~min}-$ utes as it swam and dove. This observation is one of only eight documented sightings (Edie 1973; Taylor and Gough 1977; Heise et al. 2003) of Sea Otters in waters surrounding Haida Gwaii / Queen Charlotte Islands during the past 30 years (Figure 1).

This sighting raises some interesting questions regarding the origin of this individual and whether or not Sea Otters are expanding their range to include the Haida Gwaii / Queen Charlotte Islands once again. Kenyon (1969) suggested that the most significant factor limiting the spread of Sea Otter populations is a tendency of individual Sea Otters to occupy a limited home range. Although Sea Otters are not known to migrate, as populations increase, males generally are the first to explore new areas and their presence sometimes indicates imminent range reoccupation (Loughlin 1980; Garshelis et al. 1984; Pitcher 1989). Garshelis and Garshelis (1984) recorded long-distance movements of $>100 \mathrm{~km}$ for five adult territorial males. They postulated that the Sea Otters might have left an area of limited food resources to travel to an area where food was more abundant. When Sea Otters were extirpated, many of their primary benthic invertebrate prey became larger and more abundant (Estes and Palmisano 1974; Garshelis et al. 1986). When Sea Otters recolonize they initially encounter more abundant and larger prey resources than may be expected to persist, leading to densities of Sea Otters in recovering populations greater than those that can be sustainable over 


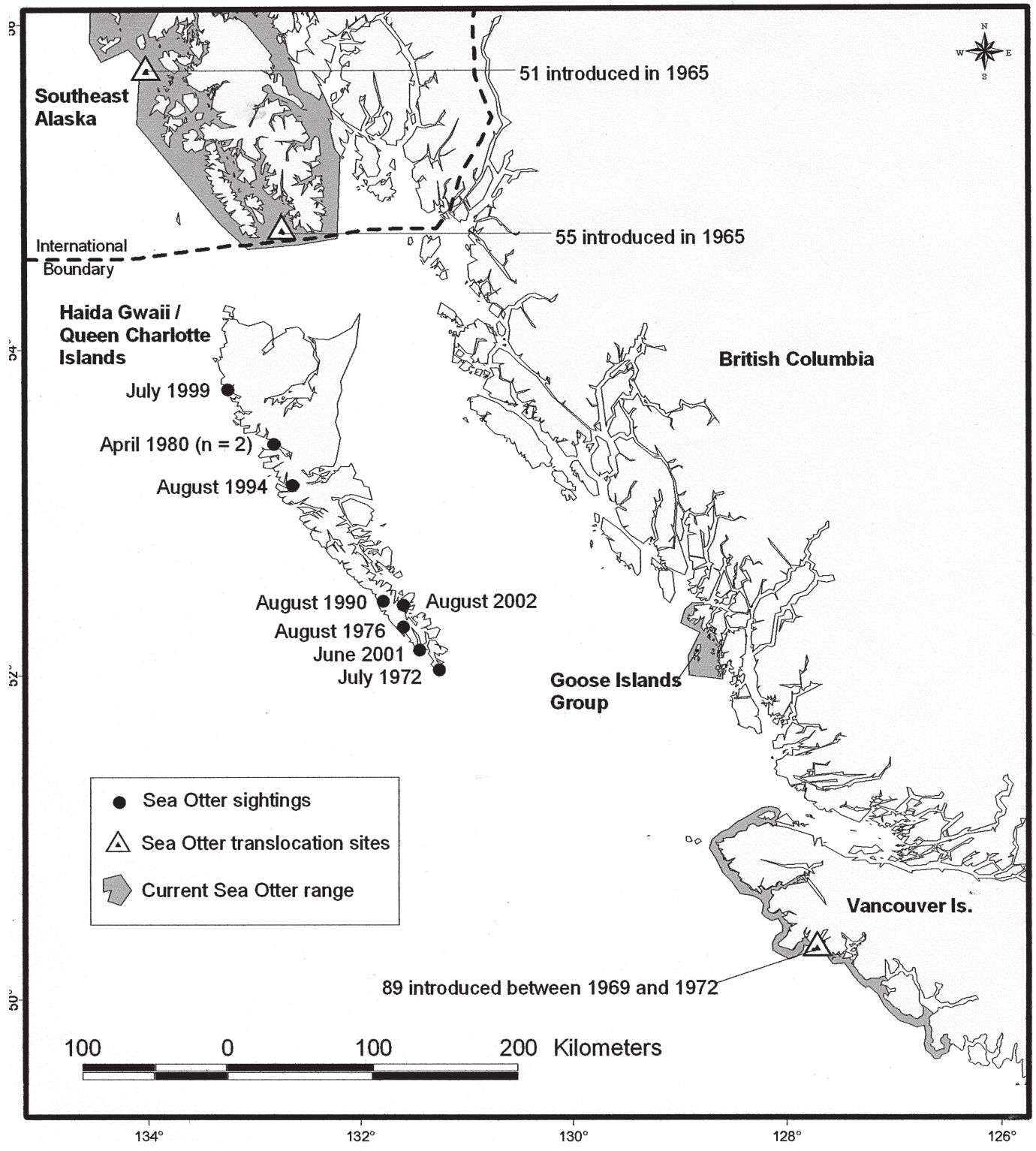

FIgURE 1. Sightings of Sea Otters around Haida Gwaii / Queen Charlotte Islands, locations of Sea Otter translocations nearest Haida Gwaii, and current Sea Otter distribution in Southeast Alaska and British Columbia (map adapted from Parks Canada Report 038, Living marine legacy of Gwaii Haanas. IV: Marine mammal baseline to 2003 and marine mammal-related management issues throughout the Haida Gwaii region by Heise et al. 2003).

time (Bodkin et al. 2000). As prey is consumed, Sea Otter densities should decline and fluctuate at an equilibrium density (Estes 1990) through decreased reproduction, increased mortality, or through emigration (Bodkin et al. 2000).

Sea Otter population increases in the Aleutian Islands were achieved largely by range expansion over deep, wide ocean passes (Estes 1990). Unless the Sea Otter we observed is a member of a previously undetected group off Haida Gwaii / Queen Charlotte Islands, this individual would have had to travel at least $175 \mathrm{~km}$ across an open expanse of water from the nearest known group of otters along the British Columbia coast (Figure 1). If this individual traveled from southeast 
Alaska or northern Vancouver Island, the distance would be even greater. If Sea Otter populations have reached or exceeded carrying capacity in certain regions of British Columbia or southeast Alaska (Watson et al. 1997; Watson 2000), this may be the beginning of the expansion of Sea Otters to their former range off Haida Gwaii / Queen Charlotte Islands. This range expansion may be particularly important given the precipitous population decline of Western Alaska Sea Otters during the past 15 years (Doroff et al. 2003) and the proposal to list the population as threatened under the United States Endangered Species Act (Federal Register: 11 February 2004; Volume 69, Number 28).

\section{Acknowledgments}

We thank the Gwaii Haanas National Park Reserve and Haida Heritage Site for allowing us to conduct Steller Sea Lion surveys (Research Permit 01-01) off Haida Gwaii, thereby allowing us to observe the Sea Otter mentioned. We are grateful to Jane Watson, Norm Sloan, Tom Gelatt, and two anonymous reviewers for their comments regarding this note.

\section{Literature Cited}

Acheson, S. 1998. In the wake of the ya'aats' xaatgáay [Iron People']: a study of changing settlement strategies among the Kunghit Haida. British Archaelogical Reports International Series 711. 209 pages.

Bigg, M. B., and I. B. MacAskie. 1978. Sea otters reestablished in British Columbia. Journal of Mammalogy 59: 874-876.

Bodkin, J. L., A. M. Burdin, and D. A. Ryazanov. 2000. Age- and sex-specific mortality and population structure in sea otters. Marine Mammal Science 16: 201-219.

Burris, O. E., and D. E. McKnight. 1973. Game transplants in Alaska. Alaska Department of Fish and Game, Game Technical Bulletin (4).

Cowan, I. M., and C. J. Guiguet. 1960. The mammals of British Columbia. British Columbia Provincial Museum Handbook (11).

Doroff, A. M., J. E. Estes, M. T. Tinker, D. M. Burn, and T. J. Evans. 2003. Sea otter population declines in the Aleutian archipelago. Journal of Mammalogy 84: 55-64.

Edie, A. G. 1973. Sea otter sighting at Cape St. James, British Columbia. Syesis 6: 265.

Estes, J. A. 1990. Growth and equilibrium in sea otter populations. Journal of Animal Ecology 59: 385-401.

Estes, J. A., and J. F. Palmisano. 1974. Sea otters: Their role in structuring nearshore communities. Science 185: 10581060 .

Garshelis, D. L., and J. A. Garshelis. 1984. Movements and management of sea otters in Alaska. Journal of Wildlife Management 48: 665-678.

Garshelis, D. L., A. M. Johnson, and J. A. Garshelis. 1984. Social organization of sea otters in Prince William Sound, Alaska. Canadian Journal of Zoology 62: 2648-2658.
Garshelis, D. L., J. A. Garshelis, and A. T. Kimker. 1986. Sea otter time budgets and prey relationships in Alaska. Journal of Wildlife Management 50: 637-647.

Heise, K. A., N. A. Sloan, P. F. Olesiuk, P. M. Bartier, and J. K. B. Ford. 2003. Living marine legacy of Gwaii Haanas IV: Marine mammal baseline to 2003 and marine mammalrelated management issues throughout the Haida Gwaii region. Parks Canada Technical Reports in Ecosystem Science Report 038. 150 pages.

Jameson, R. J., K. W. Kenyon, A. M. Johnson, and H. M. Wight. 1982. History and status of translocated sea otter populations in North America. Wildlife Society Bulletin 10: 100-107.

Jameson, R. J., K. W. Kenyon, S. Jeffries, and G. R. VanBlaricom. 1986. Status of a translocated sea otter population and its habitat in Washington. The Murrelet 67: 84-87.

Johnson, A. M. 1982. Status of Alaska sea otter populations and developing conflicts with fisheries. Pages 293-299 in Proceedings of the Forty-seventh North America Wildlife Conference, Alaska. Wildlife Management Institute, Washington, D.C.

Kenyon, K. W., and D. L. Spencer. 1960. Sea otter population and transplant studies in Alaska, 1959. U.S. Fish and Wildlife Service Special Scientific Report - Wildlife 49. 29 pages.

Kenyon, K. W. 1969. The sea otter in the eastern Pacific Ocean. North American Fauna 68: 1-352.

Loughlin, T. R. 1980. Home range and territoriality of sea otters near Monterey, California. Journal of Wildlife Management 44: 576-582.

Pitcher, K. W. 1989. Studies of the southern Alaska sea otter populations: Distribution, abundance, structure, range expansion, and potential conflicts with shellfisheries. United States Fish and Wildlife Service Cooperative Agreement Number 14-16-009-954.

Riedman, M. L., and J. A. Estes. 1990. The sea otter (Enhydra lutris): behavior, ecology and natural history. United States Fish and Wildlife Service Biological Report 90. 126 pages.

Simenstad, C. A., J. A. Estes, and K. W. Kenyon. 1978. Aleuts, sea otters, and alternate stable-state communities. Science 200: 403-411.

Sloan, N. A. 2004. Northern abalone: Using an invertebrate to focus marine conservation ideas and values. Coastal Management 32: 129-143.

Taylor, R., and B. Gough. 1977. New sighting of sea otter reported for Queen Charlotte Islands. Syesis 10: 177.

Watson, J. C. 2000. The effects of sea otters (Enhydra lutris) on abalone (Haliotis spp.) populations. Pages 123-132 in Workshop on Rebuilding Abalone Stocks in British Columbia. Edited by A. Campbell. Canadian Special Publication Fisheries and Aquatic Sciences 130.

Watson, J. C., G. M. Ellis, T. G. Smith, and J. K. B. Ford. 1997. Updated status of the sea otter, Enhydra lutris, in Canada. Canadian Field-Naturalist 111: 2: 277-286.

Received 6 August 2002

Accepted 26 August 2004 